\title{
Nest-site characteristics and breeding density of Magpie Pica pica in SOMbor (NW Serbia)
}

\section{Značilnosti gnezdišč in gnezditvena gostota srake Pica pica v Somboru (SZ Srbija)}

\author{
Thomas Oliver Mérő ${ }^{1}$, Antun Žuljević \& Katalin Varga ${ }^{3}$ \\ ${ }^{1}$ Milana Rakića 20, RS-25000 Sombor, Serbia, e-mail: thomas.oliver.mero@gmail.com \\ ${ }^{2}$ Vere Gucunje 20, RS-25000 Sombor, Serbia, e-mail: buza@ravangrad.net \\ ${ }^{3}$ Department of Ecology, Faculty of Science and Technology, University of Debrecen, Egyetem tér 1, HU-4032 \\ Debrecen, Hungary, e-mail: varg.kata@gmail.com
}

In March 2009, active Magpie Pica pica nests were censused in the town of Sombor (Vojvodina, NW Serbia) to study nest-site characteristics, breeding density and spatial distribution. The area of the town can be divided into two parts according to different urban landscapes, i.e. the town centre (150 ha) and the residential area (2,224 ha). In total, 222 Magpie nests were found and their height, tree species and nest-site type determined. Nests were found in 25 tree and two shrub species, the most of them (31.1\%) being placed in the commonest tree species in the town, the Common Hackberry Celtis occidentalis. The majority of the nests were found in tree avenues (39.6\%) and groups of trees $(31.5 \%)$. Nests in the town centre with a mean height $( \pm$ SD) of $15.2 \pm$ $4.05 \mathrm{~m}$ were significantly higher than those in the residential area with a mean height $( \pm S D)$ of $11.4 \pm 5.13 \mathrm{~m}$. The mean distance of nests from the top of the canopy $( \pm \mathrm{SD})$ was $1.5 \pm 1.33 \mathrm{~m}$, demonstrating the Magpie's tendency to place its nests in the very tops of trees in the urban areas. In the residential area, nests were present in every height class, while in the town centre they were not found lower than $5 \mathrm{~m}$. This difference can be explained by denser human population in the town centre and hence greater disturbance (e.g. pedestrians), as found in several other studies, but also by the negative effect of high buildings that prevail there. Thus, the height of surrounding buildings, too, might play an important role in nest-site selection in Magpies breeding in urban habitats, especially in densely built-up areas. Breeding density of Magpie in Sombor was 0.94 pairs $/ 10$ ha, with almost twice as high in the town centre as in the residential area. The findings of this study are compared to those obtained in other studies in Serbia and abroad.

Key words: Magpie, Pica pica, urban area, nest height, nest-site, Celtis occidentalis, Sombor, NW Serbia

Ključne besede: sraka, Pica pica, mestno območje, višina gnezda, gnezdišče, Celtis occidentalis, Sombor, SZ Srbija

\section{Introduction}

Magpie Pica pica is a common breeding species in whole Europe and beyond, occupying evenly urban, rural and natural landscapes, given that suitable nesting trees and food resources are available (CRAMP I994, BaEyens \& JeRZaK 1997). For the last 50 years,
Magpie colonised many cities where it exhibits a huge population growth in urban and suburban habitats owing to its excellent adaptation skills to this environment (JERZAK 200I). In the last few decades, many studies have been carried out about the various aspects of Magpie breeding biology, habitat selection and social organisation. As a consequence of high level 
of synurbanization, the majority of researches focus on Magpies in human settlements (e.g. BëHRMANN I968, Baeyens I979, Baeyens i98IA \& I98IB, TATNER I982, Møller i983, Birkhead et al. 1986, Bossema et al. I986, VUORISALO et al. I992, GorsKa \& GORSKI I997, Vogrin 2003, Tucakov \& KuCSERA 2008).

The aim of this study was to present the nestsite characteristics, breeding density and spatial distribution of Magpies in Sombor.

\section{Study area and methods}

\subsection{Study area}

Sombor is the town in NW Serbia with 50,590 inhabitants, total surface area of 2,950 ha (MÉrő \& ŽulJEvić 20IO), excluding suburban areas, and the average altitude of $89 \mathrm{~m}$ a.s.l. (Vojnović 200I). The town (central coordinates: $45^{\circ} 46^{\prime} \mathrm{N}, 19^{\circ} 06^{\prime} \mathrm{E}$; UTM CR57) lies in the Backa region in the NW of the northern Serbian province Vojvodina near the Great Bačka Canal (Veliki bački kanal) and the Mostonga watercourse. Sombor is a typical Pannonian town with a moderate continental climate, where the annual mean precipitation is about $596 \mathrm{~mm}$. The warmest month is July with a monthly mean temperature of $20.9^{\circ} \mathrm{C}$, while January is the coldest with a monthly mean temperature of $0.9^{\circ} \mathrm{C}$ (Тomić 1996).

Sombor is one of the greenest towns in Serbia, because of its large cover of urban vegetation, whereas the natural or semi-natural vegetation cover has almost disappeared. Trees are planted in form of tree avenues, parks and park-forests. Parks cover $0.4 \%$ (10 ha) of the entire surface area of the town, while the green areas along streets on house plots and other vegetation cover $7.1 \%(176 \mathrm{ha})$ and lawns $2.1 \%$ (51.5 ha). The tree avenues, which are altogether $121 \mathrm{~km}$ long, contain about 18,000 trees (VoJnović 200I). The most common tree, and the town symbol, is the Common Hackberry Celtis occidentalis (60\% of all trees within the avenues), while Linden Tilia sp. (14\%), Maples Acer sp. (8\%), Black Locust Robinia pseudacacia (7\%), Poplar Populus sp. (5\%), Horse Chestnut Aesculus hippocastanum (3\%) and Japanese Pagoda Tree Sophora japonica (1\%) are less common. In the yards of the houses, many conifers, fruittrees and Common Walnuts Juglans regia have been planted (Vojnović 200I, T. Sкокіć pers. comm.). The shrub habitats that have decreased in the last decade in Sombor are mostly non-planted and mainly contain species like Black Lace Elderberry Sambucus nigra, Blackthorn Prunus spinosa and Dog Rose Rosa canina.
The studied area of the town $(2,374 \mathrm{ha})$ can be divided into two parts according to the different urban landscape: (1) In the town centre (150 ha), there are short wide streets with young planted trees and mostly older and higher $19^{\text {th }}$ and $20^{\text {th }}$ century buildings usually with very small yards. The town centre contains The Cube Avenue (strict centre of the town) surrounded by 4-5 tree rows. The part within the Cube Avenue contains only few years old trees and buildings mainly from the 19th century. One of the parks is located in the town centre. There are no meadows with herbaceous vegetation. (2) The remaining part $(2,224 \mathrm{ha})$ of the town is the residential area, built up mainly by houses and partially by modern buildings with large yards and gardens. Some districts contain skyscrapers with small streets, where plane trees Platanus sp. are planted along the avenues. There are also two parks. At the periphery, orchards can be found as well, although most of them are abandoned. The periphery also contains the Mostonga watercourse, Great Bačka Canal and three park-forests. These parts of the town can be classified as suburban.

\subsection{Methods}

Our census was carried out in the whole town area, together with nearby semi-rural areas that are actually part of the town. In order to achieve this, we checked every street, park, large yard, orchard and ruderal shrubby habitat in the town by bicycle to search for Magpie nests. The duration of the fieldwork was $10 \mathrm{~h}$ per day. Nests were censused from 26 to $31 \mathrm{Mar}$ 2009 , in the season when tree canopies are without leaves and nests can be spotted easily. Despite the fact that egg-laying by Magpies generally starts only in April (Cramp 1994), we chose the end of March for our census, as this is the period of intensive nest building and territorial behaviour that makes these birds highly conspicuous. The information on the nest being occupied by a breeding pair was considered sufficient for the main objective of this study. Only active nests (i.e. occupied by Magpie pairs, bringing nest material, observation of adults in the nest, on the nest edge or flying off from the nest) have been taken in consideration and all were registered on a map. Nest height was measured from the ground to the lower nest edge to the nearest meter. This parameter has been checked twice, as well as the distance between the top of the canopy and the lower nest edge.

Woody vegetation with nests located was distinguished according to its height, surface area and function in the town into the following categories, representing different nest-site types: solitary tree, 


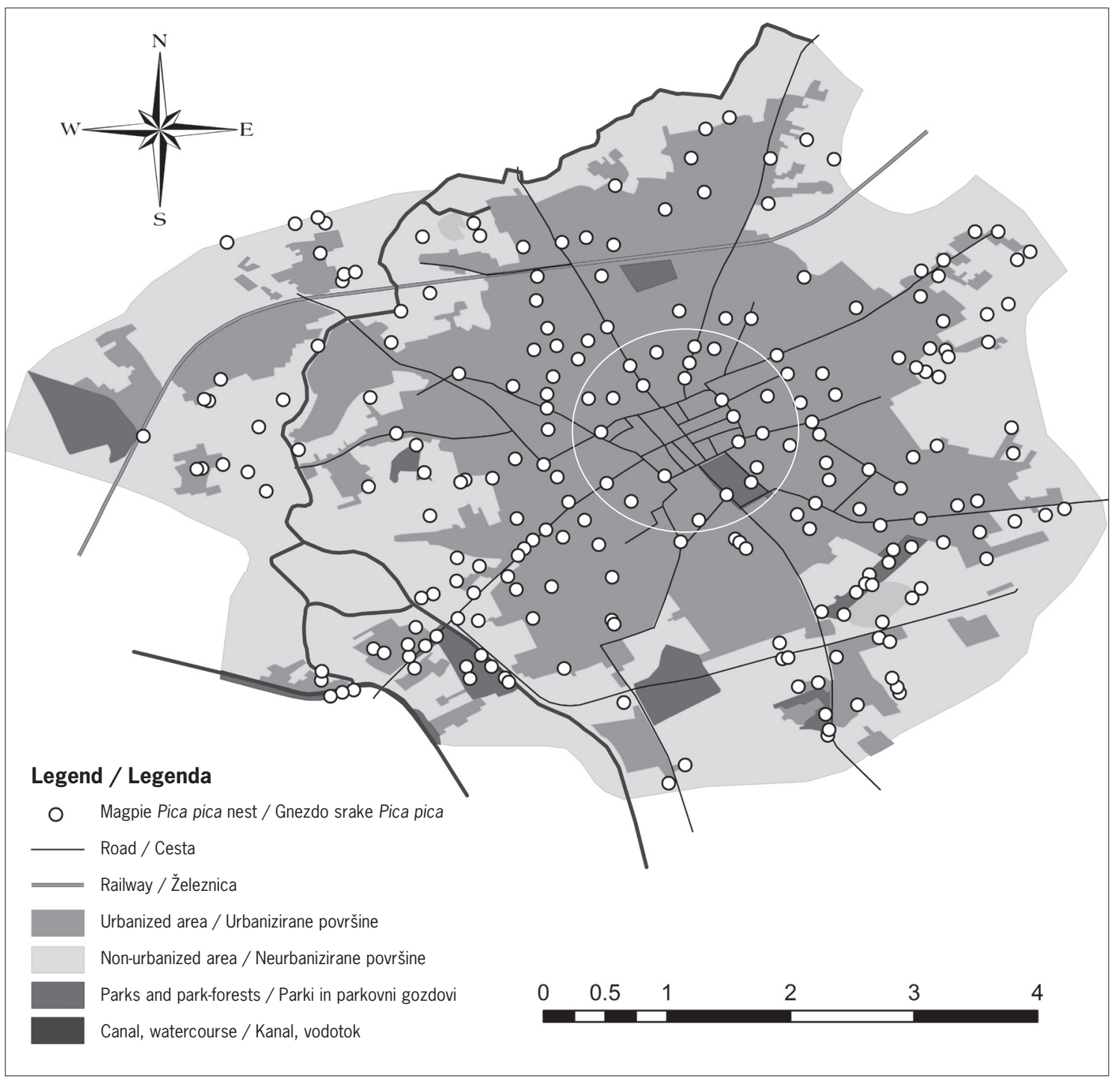

Figure 1: Distribution of Magpie Pica pica nests over the study area of Sombor in 2009. White circle separates the town centre from the residential area.

Slika 1: Razširjenost gnezd srake Pica pica na raziskovanem območju mesta Sombor leta 2009. Bel krog ločuje mestno središče od stanovanjskega okoliša.

group of trees (several trees growing closely together), orchard (mainly abandoned), tree avenue, park (larger area planted with trees and smaller meadows in between), park forest (large area where trees are densely planted) and shrubs.

\section{Results}

We recorded a total of 222 Magpie nests in the entire studied territory of Sombor (Figure 1). Due to the high accuracy of our census, we estimate the actual size of the breeding population here at $220-230$ pairs. We found nests in 25 different tree species and two shrub species, Blackthorn and Honey Locust Gleditschia triacanthos. Overall, only 15 (6.8\%) Magpie nests were placed in conifers, while the rest were found in broadleaved trees. The most nests $(31.1 \%)$ were found in the town's commonest tree species, the Common Hackberry (Table 1). 
T. O. Mérő, A. Žuljević \& K. Varga: Nest-site characteristics and breeding density of Magpie Pica pica in Sombor (NW Serbia)

Table 1: Tree species with Magpie Pica pica nests found

Tabela 1: Vrste dreves z najdenimi gnezdi srake Pica pica

\begin{tabular}{lcc}
\hline Tree species / Vrsta drevesa & $\begin{array}{c}\text { No. of nests/ } \\
\text { Št. gnezd }\end{array}$ & $\begin{array}{c}\text { Percentage/ } \\
\text { Odstotek (\%) }\end{array}$ \\
\hline Celtis occidentalis & 69 & 3 I.I \\
Robinia pseudacacia & 25 & II.3 \\
Prunus sp. & I8 & $8 . \mathrm{I}$ \\
Ulmus pumila & I2 & 5.4 \\
Acer sp. & II & 5.0 \\
Betula pendula & II & 5.0 \\
Juglans regia & II & 5.0 \\
Sophora japonica & II & 5.0 \\
Populus sp. & 9 & 4.1 \\
Picea abies & 8 & 3.6 \\
Populus nigra var. italica & 6 & 2.7 \\
Acer campestre & 4 & I.8 \\
Pinus nigra & 3 & I.4 \\
Platanus hybrida & 3 & I.4 \\
Tilia sp. & 3 & I.4 \\
Cedrus atlantica & 2 & 0.9 \\
Cerasus sp. & 2 & 0.9 \\
Fraxinus sp. & 2 & 0.9 \\
Gleditschia triacanthos & 2 & 0.9 \\
Pinus wallichiana & 2 & 0.9 \\
Salix sp. & 2 & 0.9 \\
Morus alba & I & 0.5 \\
Prunus spinosa & I & 0.5 \\
Pyrus sp. & I & 0.5 \\
Quercus robur & I & 0.5 \\
Sambucus nigra & I & 0.5 \\
Thuja sp. & I & 0.5 \\
\hline Total / Skupaj & 222 & IOO.0 \\
\hline & & \\
\hline
\end{tabular}

Overall, nests were placed at a mean height $( \pm \mathrm{SD})$ of $11.8 \pm 5.16 \mathrm{~m}$ (range $=2-25 \mathrm{~m}$ ). The lowest nests were found in cherry species Cerasus sp., plum species Prunus sp. and Black Locust, the highest in Black Poplar Populus nigra var. italica. In the residential area, nests were present in every height class. In the town centre, nests were not found lower than $5 \mathrm{~m}$ (Figure $2)$. Nests in the town centre with a mean height $( \pm S D)$ of $15.2 \pm 4.05 \mathrm{~m}$ (range $=10-25 \mathrm{~m}$ ) were significantly higher than those in the residential area with a mean height $( \pm$ SD) of $11.4 \pm 5.13 \mathrm{~m}($ range $=2-25 \mathrm{~m})$ ( $t$-test, $t=3.43, \mathrm{df}=220, P=0.0007)$. The highest nests in the town centre were found in Linden, while the highest nests in the residential area were placed in Hybrid Plane Platanus hybrida and Poplar.

Mean height of the woody vegetation in which nests were recorded $( \pm S D)$ was $13.1 \pm 5.44 \mathrm{~m}$ (range

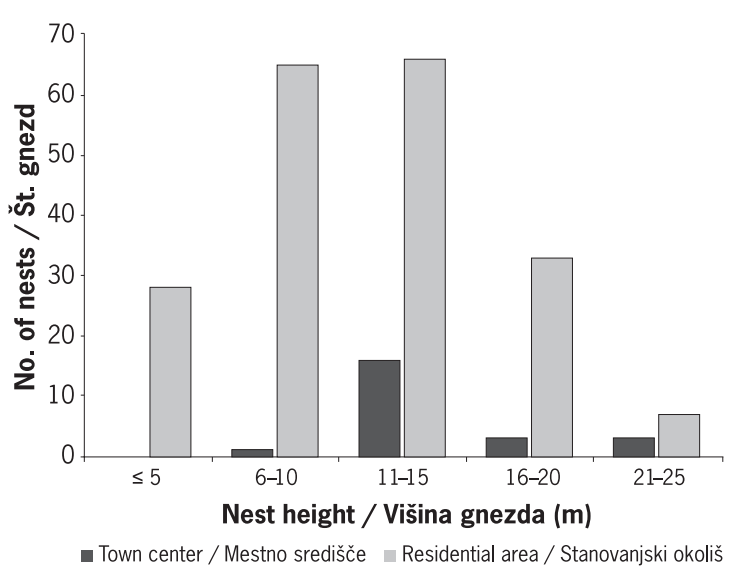

Figure 2: Number of Magpie Pica pica nests recorded in different height classes

Slika 2: Število gnezd srake Pica pica, zabeleženih v različnih višinskih razredih

$=2.5-28 \mathrm{~m})$. The mean distance of nests from the top of the canopy $( \pm \mathrm{SD})$ was $1.5 \pm 1.33 \mathrm{~m}$ (range $=$ $0-10 \mathrm{~m}$ ). The same parameters are given separately for both parts of the town in Table 2. We found strong correlation between nest height and height of the trees $\left(r_{s}=0.99, \mathrm{df}=220, P=0.017\right)$. There was a significant difference between the height of trees containing Magpie nests in the town centre and in the residential area $(t$-test, $t=2.81, \mathrm{df}=220, P=0.0054)$.

The majority of nests were found in tree avenues $(39.6 \%)$ and groups of trees (31.5\%), while the lowest number of nests was recorded in solitary trees (Table 3).

The overall breeding density of Magpies in Sombor was 0.94 pairs $/ 10$ ha. Our results showed that $10.4 \%$ of the population bred in the town centre, where the density of the breeding pairs was 1.53 pairs/10 ha. In the residential area of the town, the breeding density was only 0.89 pairs/10 ha. In the strict centre of the town (Cube Avenue), no nests were found.

\section{Discussion}

In our study, we found a significant difference between tree height and nest height in the town centre and in the town's residential area. However, the nest height in both parts of the town correlated with tree height. In Sombor, the Magpie generally builds its nests at the greatest possible height in the very top of the canopy, irrespective of the part of the town. However, there was an important difference between the town centre and the residential area: about $10 \%$ of the nests in the residential area were placed at heights less than $5 \mathrm{~m}$, in some cases even less than $2 \mathrm{~m}$, which was not 
Table 2: Magpie Pica pica nest-site characteristics in two different parts of Sombor

Tabela 2: Značilnosti gnezdišč srake Pica pica na dveh različnih delih mesta Sombor

\begin{tabular}{|c|c|c|c|c|c|}
\hline $\begin{array}{l}\text { Part of the town/ } \\
\text { Del mesta }\end{array}$ & $\begin{array}{l}\text { Surface area/ } \\
\text { Površina (ha) }\end{array}$ & $\begin{array}{l}\text { No. of nests/ } \\
\text { St. gnezd }\end{array}$ & $\begin{array}{l}\text { Mean nests } \\
\text { height/ } \\
\text { Povprečna višina } \\
\text { gnezd }( \pm \text { SD) }(\mathrm{m})\end{array}$ & $\begin{array}{l}\text { Mean height of trees } \\
\text { with nests/ } \\
\text { Povprečna višina } \\
\text { dreves z gnezdi } \\
( \pm \mathrm{SD})(\mathrm{m})\end{array}$ & $\begin{array}{l}\text { Mean distance of nests } \\
\text { from top of canopy/ } \\
\text { Povprečna razdalja } \\
\text { gnezd od vrha krošnje } \\
\quad( \pm \text { SD })(m)\end{array}$ \\
\hline $\begin{array}{l}\text { Town Centre/ } \\
\text { Mestno središče }\end{array}$ & 150 & 23 & $15.2 \pm 4.05$ & I6.I \pm 3.76 & I.I \pm 0.80 \\
\hline $\begin{array}{l}\text { Residential area/ } \\
\text { Stanovanjski okoliš }\end{array}$ & 2,224 & 199 & II. $4 \pm 5 . \mathrm{I} 3$ & $\mathrm{I} 2.8 \pm 5.48$ & I. $5 \pm \mathrm{I} .38$ \\
\hline Total / Skupaj & 2,374 & 222 & II. $8 \pm 5.16$ & $\mathrm{I} 3 . \mathrm{I} \pm 5.44$ & I. $5 \pm \mathrm{I} .33$ \\
\hline
\end{tabular}

the case in the town centre. We explained this with denser human population in the town centre and hence greater disturbance that affects nest height of the Magpie. Furthermore, we presume that high buildings prevailing in the town centre also affect nest height there, i.e. only higher trees are selected for nest placing. It is well known that Magpies place their nest higher up in urban environments due to the increases in human disturbance (e.g. the number of pedestrians) and predation risk (JERZAK 200I, WANG et al. 2008). In addition to that, we argue that as buildings get lower in the residential area, the lower height-limit of the selected nest-sites is reduced as well. Therefore, the height of the surrounding buildings might play an important role in nest-site selection in Magpies breeding in urban habitats, especially in densely builtup areas.

Table 3: Number of Magpie Pica pica nests recorded in different nest-site types

Tabela 3: Število gnezd srake Pica pica, zabeleženih na različnih tipih gnezdišč

\begin{tabular}{lcc}
\hline Nest-site type / Tip gnezdišča & $\begin{array}{c}\text { No. of } \\
\text { nests/ } \\
\text { St. gnezd }\end{array}$ & $\begin{array}{c}\text { Percentage/ } \\
\text { Odstotek } \\
(\%)\end{array}$ \\
\hline Tree avenue / Drevored & 88 & 39.6 \\
Group of trees / Skupina dreves & 70 & 31.5 \\
Shrubs / Grmi & I9 & 8.6 \\
Park / Park & I4 & 6.3 \\
Orchard / Sadovnjak & I4 & 6.3 \\
Park-forest / Parkovni gozd & II & 5.0 \\
Solitary tree / Posamezno drevo & 6 & 2.7 \\
\hline Total / Skupaj & 222 & IOO.0 \\
\hline
\end{tabular}

In Novi Sad, the second largest city of Serbia, the majority of nests were placed between 11 and $20 \mathrm{~m}$, average $15.8 \mathrm{~m}$ (TUCAKOv \& KUCSERA 2008), which is higher than the overall average nest height in this study $(11.8 \mathrm{~m})$. Studies carried out in rural areas abroad reported considerably lower average nest heights than in Serbian urban areas (Tucakov \& Kucsera 2008, this study) and elsewhere (Cramp \& Perrins i994, WANG et al. 2008) - e.g. in the Krapina river valley (Croatia), the nest height mean was $6.74 \mathrm{~m}$, range 1-16 m (Dolenec 2000), whereas in Slovenia it was $5.7 \mathrm{~m}$ (Vogrin I998). However, in Sofia (Bulgaria) the mean nest height was $6.9 \pm 3.15 \mathrm{~m}$ (range $1.2-14 \mathrm{~m}$ ) (Antonov \& Atanasova 2002), which is more similar to the nest heights found in rural habitats. Mean distance of the nests from the top of the canopy in this study was similar to the average value obtained for Novi Sad $(1.3 \mathrm{~m}$, range 0.5-5 m) (Tucakov \& KuCSERA 2008), demonstrating the Magpie's tendency to place nests in very tops of trees in urban areas (Cramp \& Perrins 1994). Nests were found mainly in tree avenues and groups of trees in Sombor, which is similar to the results of observations by TuCAKov \& KuCSERA (2008), where Magpies preferred all green areas at first $(32.8 \%)$, followed by groups of trees $(31.2 \%)$ and tree avenues (21.1\%).

The most nests in the town were found in the commonest planted tree species, the Common Hackberry. Similarly, in Novi Sad Magpies mostly used plane trees $(17.2 \%)$ and European Hackberry Celtis australis (14.8\%) for nesting (TuCAKov \& Kucsera 2008). In Sofia, the most preferred tree species were Black Poplar, Douglas Fir Pseudotsuga menziesii and Blue Spruce Picea pungens (AnTONOv \& Atanasova 2002). A study in rural habitats concluded that Magpies mainly (59.7\%) place their nests in 
willows Salix sp. and Blackthorn bushes (DoleneC 2000). Tucakov \& Kucsera (2008) found Magpie nests in 24 tree and bush species, while VoGRIN (I998) found them, during his study at Dravsko Polje (NE Slovenia), in 14 woody plant species. These findings confirm the reported wide range of nesting tree species used by Magpies, generally according to their local abundance (Cramp \& Perrins 1994). However, in the places where tree stands are young and thus not high enough, nesting was not recorded during our study (e.g. within the Cube Avenue). Likewise, we found few or no nests in some common tree species with crown physiognomy evidently less suitable for nest placement.

The overall breeding density of Magpie in Sombor was 0.94 pairs $/ 10$ ha. Furthermore, the breeding density was almost double in the town centre than in the residential area of Sombor. However, breeding densities cannot be directly compared between the town centre and the residential area due to their great difference in their respective surface areas (i.e. residential area is more than 10-times larger). It is well known that breeding density is the function of the surface area (BEZZEL 1982). We presume that owing to the much smaller surface area of the town centre, the calculated density appears higher there. Also, the distribution of Magpie nests in the town is not uniform as in both parts areas with very high density as well as large areas with no nests whatsoever can be found. We presume the cause for this nonuniform distribution lies in differences in tree stands distribution over the studied area of the town - the areas with high tree stands (parks, avenues etc.) contain most of the nests, while in the areas with poor tree stands the nest density is low. In similar urban habitats of Novi Sad, the breeding density was 1.97 pairs/10 ha (TuCAKov \& KuCSERA 2008). Slovenian research reports on different densities in urban habitats; in Maribor 0.34 pairs/10 ha, Celje 0.61 pairs/10 ha, Ptuj 0.65 pairs/10 ha, Slovenska Bistrica 0.41 pairs/10 ha and in Žalec 0.52 pairs/10 ha (Vogrin 2003). Although it was higher in Novi Sad, we conclude that the breeding density in Sombor is not low in general, considering the breeding densities found in various Slovenian towns. According to BAuer et al. (2005), the breeding densities in large cities of Central Europe vary between 0.6 and 1.4 territories/10 ha, while in smaller cities (up to 300,000 inhabitants) they do not exceed 2.1 pairs/10 ha. The incredibly high density recorded in Sofia (Bulgaria) in the 405 ha large study area, i.e. 5.18 pairs/10 ha in 1999 and 5.68 pairs/10 ha in 2000, is exceptional (Antonov \& Atanasova 2002). In their study, Tucakov \& Kucsera (2008) mention three reasons as an explanation for the high density of Magpies in Novi Sad: easy food accessibility, presence of many high and old enough trees among buildings, and low nest predation by Hooded Crows Corvus cornix. We presume these assertions are all true for Magpies breeding in Sombor, too. Here, the suitable tree stand between the buildings is extensive and because Hooded Crow population was estimated at only 3-5 breeding pairs (Mérő \& ŽUlJević 2OIO), Magpie nest predation by this species is reputedly low, the same as competition between the two species. TuCaKov \& Kucsera (2008) observed that open trash containers (higher numbers in more populated plots) might increase food accessibility for Magpies in Novi Sad. According to our observations, the illegal dumps on the outskirts of the town might play a similar role in Sombor instead.

We censused Magpie nests at the end of nestbuilding and at the beginning of egg-laying periods. According to the study by Møller (1983), Magpie nests are built between 4 Mar and 12 Apr, while replacement nests are established from 1 to 12 Apr. However, Magpies characteristically lay their eggs in urban landscapes earlier than in rural habitats (Chamberlain et al. 2009). Still, there was a possibility in this study that some nests were built after the period of our census, although those were most probably replacement clutches as these are in Magpies usually laid in new nests built quickly after the loss of 1st clutch (Cramp \& Perrins i994, Bauer et al. 2005).

Acknowledgements: We thank Enikő Anna Tamás for checking the manuscript.

\section{Povzetek}

Marca 2009 so avtorji prispevka popisovali aktivna gnezda srake Pica pica v Somboru (Vojvodina, SZ Srbija), da bi natančno preučili značilnosti gnezdišč teh ptic, a tudi njihovo gnezditveno gostoto in prostorsko razširjenost. Mestno območje je glede na njegovo različno urbano krajino mogoče razdeliti na dva dela, in sicer na mestno središče (150 ha) in stanovanjski okoliš (2224 ha). Skupaj so popisali 222 sračjih gnezd in pri tem ugotavljali višino posameznih gnezd, vrste dreves, na katerih so gnezdile, in tipe gnezdišč. Srake so gnezdile na drevesih in grmih 25 različnih vrst, večinoma $(31,1 \%)$ na ameriškem koprivovcu Celtis occidentalis, ki je najpogostejša drevesna vrsta $v$ mestu. Večina gnezd je bila zabeležena v drevoredih $(39,6 \%)$ in skupinah dreves $(31,5 \%)$. Gnezda v mestnem središču s povprečno višino $( \pm S D)$ $15,2 \pm 4,05 \mathrm{~m}$ so bila pomembno višja kot drevesa 
v stanovanjskem okolišu s povprečno višino $( \pm S D)$ $11,4 \pm 5,13 \mathrm{~m}$. Povprečna razdalja gnezd od vrha krošnje $( \pm S D)$ je bila $1,5 \pm 1,33 \mathrm{~m}$, kar kaže na srakino tendenco, da si v urbanih območjih gnezda spleta $\mathrm{v}$ samih vrhovih dreves. V stanovanjskem okolišu so bila gnezda najdena na vseh drevesnih višinah, medtem ko jih v mestnem središču niže od $5 \mathrm{~m}$ ni bilo zaslediti. To razliko je mogoče pojasniti z gostejšo populacijo prebivalstva $\mathrm{v}$ mestnem središču in zatorej $\mathrm{z}$ večjim vznemirjanjem (na primer $s$ strani pešcev), kot že ugotovljeno v mnogih drugih študijah, hkrati pa tudi $\mathrm{z}$ negativnim vplivom visokih stavb, ki prevladujejo $\mathrm{v}$ tem delu mestu. V izbiri gnezdišč teh ptic, ki gnezdijo $\mathrm{v}$ urbanih habitatih, še posebno $\mathrm{v}$ gosto pozidanih območjih, lahko pomembno vlogo zatorej igra tudi višina obdajajočih zgradb. Gnezditvena gostota srak v Somboru je bila 0,94 para/ 10 ha, le da je bila v mestnem središču skoraj dvakrat večja kot $\mathrm{v}$ stanovanjskem okolišu. Izsledki te študije avtorji primerjajo z izsledki drugih študij, opravljenih v Srbiji in tujini.

\section{References}

Antonov, A. \& Atanasova, D. (2002): Nest-site selection in the Magpie Pica pica in a high-density urban population of Sofia (Bulgaria). - Acta Ornithologica 37: 55-66.

Baeyens, G. (I979): Description of the social behaviour of the Magpie (Pica Pica). - Ardea 67: 28-41.

BAEYENS, G. (I98IA): The role of the sexes in territory defence in the Magpie (Pica Pica). - Ardea 69: 69-82.

Baeyens, G. (I98IB): Magpie breeding success and Carrion Crow interference. - Ardea 69: 125-139.

Baeyens, G. \& Jerzak, J. (I997): Magpie Pica pica. pp. 672-673 In: Hagemeijer, J.M.W. \& Blair J.M. (eds.): The EBCC Atlas of European Breeding Birds: Their Distribution and Abundance. - T \& A D Poyser, London.

Bauer, H.G., Bezzel, E. \& Fiedler, W. (eds.) (2005): Das Kompendium der Vögel Mitteleuropas. - AULA Verlag, Wiebelsheim.

Bährmann, U. (I968): Die Elster. - Neue Brehm-Bücherei. A. Ziemsen, Wittenberg - Lutherstadt.

Bezzel, E. (1982): Vögel in der Kulturlandschaft. - Ulmer, Stuttgart.

Birkhead, T.R., Eden, S.F., Clarkson, K., Goodburn, S.F. \& Pellatt, J. (I986): Social organisation of a population of Magpies Pica pica. - Ardea 74: 59-68.

Bossema, I., Röell, A. \& Baeyens, G. (I986): Adaptations to interspecific competition in five corvid species in the Netherlands. - Ardea 74: 199-210.

Chamberlain, D.E., Cannon, A.R., Toms, M., Leech, D., Hatchwell, B. \& Gaston, K. (2009): Avian productivity in urban landscapes: a review and meta-analysis. - Ibis 151: $1-18$.
Cramp, S. \& Perrins, C.M. (ed.) (i994): Handbook of the Birds of Europe, the Middle East and North Africa. The birds of the western Palearctic. Vol. 8. Crows to Finches. - Oxford University Press, Oxford.

Dolenec, Z. (2000): Breeding density, nest sites, clutch size and egg dimensions of Magpie (Pica pica) in NW Croatia. - Natura Croatica 9: 107-114.

Gorska, E. \& Gorski, W. (1997): Nest sites of the Magpie Pica pica in urban and rural habitats in the Koszalin Region, NW Poland. - Acta Ornithologica 32: 45-50.

JERZAK, L. (200I): Synurbanization of the magpie in the Palearctic. pp. 403-425 In: Marzluff, M.J., Bowman, R. \& Donnelly, R. (eds.): Avian Ecology and Conservation in an Urbanizing World. - Kluwer Academic Publishers, Norwell.

Mérő, T.O. \& Žuljević, A. (20Io): Ptice Sombora. - Društvo za zaštitu i proučavanje prirode - Natura, Sombor.

Møller, A.P. (1983): Habitat selection and feeding activity in the Magpie Pica pica. - Journal of Ornithology 124: $147-161$.

TATner, P. (1982): Factors influencing the distribution of Magpies Pica pica in an urban environment. - Bird Study 29: 227-234.

Tomić, P. (I996): Klima. pp. 16-21 In: Đuričıć, J. (ed.): Opština Sombor. - Prirodno-matematički fakultet, Institut za geografiju \& Prosveta, Novi Sad.

Tucakov, M. \& Kucsera, I. (2008): Nest site selection and density of Magpie Pica pica in Novi Sad (Serbia). Vogelwelt 129: 97-101.

Vogrin, M. (1998): Density, nest site and breeding success of a rural population of the Magpie (Pica pica) in NE Slovenia. - Vogelwarte 39: 293-297.

Vogrin, M. (2003): Common Magpie Pica pica, Western Jackdaw Corvus monedula and Hooded Crow Corvus cornix in some towns in North-eastern Slovenia (Central Europe). - Online Journal of Biological Sciences 3 (8): 688-693. - [http://docsdrive.com/pdfs/ansinet/ jbs/2003/688-693.pdf]

Vojnović, M. (200I): Sombor. - Publikum, Sombor.

Vuorisalo, T., Hugg, T., Kaitainiemi, P., Lappalainen, J. \& Vesanto, S. (I992): Habitat selection and nest sites of the Magpie Pica pica in the city of Turku, SW Finland. Ornis Fennica 69: 29-33.

Wang, Y., Chen, S., Jiang, P. \& Ding, P. (2008): Blackbilled Magpies (Pica pica) adjust nest characteristics to adapt to urbanization in Hangzhou, China. - Canadian Journal of Zoology 86 (7): 676-684.

Arrived / Prispelo: 28.5.2009

Accepted / Sprejeto: 22.6.2011 